\title{
DECLINING US INFLUENCE AND RISE OF LATIN AMERICA'S REGIONAL POWER: SOME LESSONS FOR THE MIDDLE EAST
}

\author{
EVREN ÇELIK WILTSE*
}

\begin{abstract}
This article highlights the recent changes in US-Latin American relations and the consequences of gradually shifting power balance for the Latin American countries. After providing a brief history of hemispheric relations, it analyzes the post-Cold War dynamics. Particular emphasis is placed on recent economic performances and democratic progress achieved by most Latin American nations. In the final section, this article acquires a comparative lens and draws some conclusions for Turkey and the Middle East in light of the Latin American experience. It argues that endemic security threats and high military spending in the Middle East hinder the virtuous cycle of regional solidarity, cooperation and development.
\end{abstract}

\section{KEYWORDS}

US-Latin American Relations, Democratization, Regional Development, Hegemonic Decline, Middle East, Turkey

*Evren Çelik Wiltse is a Research Assistant in the Department of International Relations, Hacettepe University, Ankara, Turkey. 
Dynamics between Latin America and the US have never been static. There have been numerous historic stages, largely determined by the political and economic status of either side. Table 1 below tries to summarize the main episodes of an approximately 200 year long history of relations. This article, however, focuses mostly on the postCold War era. It analyzes the latest and most important dynamics in the hemispheric relations. The consolidation of Latin America as a region, and its robust performance in economic growth and democratic governance will be mentioned in the following sections. In the final section, this article acquires a comparative lens and attempts to draw some conclusions for Turkey and the Middle East in light of the Latin American experience.

TABLE 1: Historical Periods in US-Latin American Relations

\begin{tabular}{|c|c|c|c|}
\hline & $\begin{array}{l}\text { US Foreign } \\
\text { Policy } \\
\text { DOCTRINE } \\
\end{array}$ & PRIORITIES & METHODS \\
\hline $\begin{array}{l}1800- \\
\text { World } \\
\text { War II }\end{array}$ & $\begin{array}{l}\text { Manifest Destiny } \\
\text { Monroe Doctrine } \\
\text { Roosevelt } \\
\text { Corollary }\end{array}$ & $\begin{array}{l}\text { Establishing } \\
\text { hegemony in } \\
\text { Western } \\
\text { Hemisphere }\end{array}$ & $\begin{array}{l}\text {-Territorial expansion } \\
\text { (by war or purchasing) } \\
\text {-Restraining the role of } \\
\text { Europe in LA }\end{array}$ \\
\hline $\begin{array}{l}\text { Cold War } \\
\text { Era }\end{array}$ & Containment & $\begin{array}{l}\text { Regional Stability } \\
\text { Fight against } \\
\text { communism }\end{array}$ & $\begin{array}{l}\text {-Economic sanctions } \\
\text {-Covert operations } \\
\text {-Military interventions }\end{array}$ \\
\hline $\begin{array}{l}\text { Post-Cold } \\
\text { War Era }\end{array}$ & $\begin{array}{l}\text { Neoliberalism } \\
\text { (Washington } \\
\text { Consensus) } \\
\text { Liberal } \\
\text { democracy }\end{array}$ & $\begin{array}{l}\text { Establishing free } \\
\text { market economies } \\
\text { Immigration } \\
\text { Border security }\end{array}$ & $\begin{array}{l}\text {-Free trade agreements } \\
\text { (ex. NAFTA,FTAA) } \\
\text {-Anti-drug trafficking } \\
\text { programs } \\
\text {-Anti-immigration } \\
\text { measures }\end{array}$ \\
\hline
\end{tabular}

Table 1 above summarizes predominant US foreign policy doctrines in relation to Latin America, as well as the priorities and methods that are attached to each of these doctrines. The period staring from the independence of Latin American Republics in the early 1800s until the World War II could be captured under the 
Monroe Doctrine. This is a period of hegemonic build up for the US. Therefore, direct and intense military interventions are relatively few when compared to the Cold War era.

The period when the US felt Latin America strongly as its "backyard", was the Cold War era. The frequency and intensity of overt/covert operations in the region created such traumas in Latin America that their effects still linger in some parts. Throughout the 1990s, however, direct military interventions were out of fashion. Instead, this final era was shaped by new economic models that originated from the US or US-dominated international financial institutions, such as the IMF and the World Bank.

\section{Brief Historical Background}

It is important to have some discussion of the pre-1800 conditions in Latin America, in order to better comprehend the current dynamics in US-Latin American relations. As we all very well know, the first people to "discover" and colonize the area known as Latin America today, were the Spaniards. Eventually, the Portuguese, the British, the French also joined these excursions in the New World and began dividing the continent into separate spheres of domination. The Spanish and the Portuguese focused largely on Southern America while the British and the French established their settlements in the North.

This differentiation that started from the colonial era had important consequences for the Americas. Today if we wonder why Brazil and Argentina -which are just as rich in natural resources as the US-, cannot become superpowers like the US, the answer largely lies in the history.

The most important divisions between North and South America were established as they were being colonized. The colonization practices of the Spaniards and the British were drastically different. The early colonizers (Spanish and the Portuguese) were mesmerized by the gold and silver accessories of the Aztecs and Mayas and began to search frantically for "El Dorado". Their ultimate goal was to find the golden cities and take all these riches back to the Iberian Peninsula. Because of this, they 
created a huge destruction everywhere they went. Indigenous population declined rapidly, due to extreme working conditions in the mines. Approximately a quarter of the remaining population died because of infections diseases that the Europeans brought, such as chicken pox and measles. Natives did not have immunity systems to fight against these diseases.

The Spanish and Portuguese elites saw Latin America as an opportunity for quick riches, hence did not initially bring their families into this "wild" frontier. Thus, they had problems to get permanently settled. Aside from this, there was also the fact that when the initial colonial adventures began in Latin America in the 1550s, Spain and Portugal were living the Middle Ages. Consequently, they did not have the advantages of the Enlightenment and rational thinking, which caused revolutionary transformations for humanity. Instead, there were long debates in front of the Spanish Crown about whether the indigenous persons were human beings or some other forms of living. The Conquest was taking place at the peak of the Inquisition and thus, was reflecting the most intolerant and conservative interpretations of Catholic thinking. In short, this particular superstructure (pre-Enlightenment, dogmatic) helped to establish dogmatic, authoritarian and rather centrist colonial regimes in the New World. ${ }^{1}$

Compared to Latin America, the US had the advantage of being a late colony. In the meantime, most countries in Continental Europe and England had encountered the ideas of Enlightenment, rationalism, free thinking and even the seeds of democratic rule. All of these concepts were exported primarily to the US. Even economically, the US had a comparative advantage because, unlike the Spaniards, the British had realized the "fruits" of free trade. While the Spaniards were still stuck in mercantilism and bullionism, the British were establishing a huge network of trade and commerce relations across the world. After independence, the US took over this network and utilized it successfully to boost its economy.

\footnotetext{
${ }^{1}$ On the intellectual, social and structural impacts of the Spanish Empire in Latin America, see Howard Wiarda, The Soul of Latin America, New Have, Yale University Press, 2003. For a classic study of political tradition in Latin America, see Claudio Veliz, The Centrist Tradition in Latin America, Princeton/NJ, Princeton University Press, 1980.
} 
Another important difference between the US and Latin America was in their respective settlement patterns. In the North, the colonizers came with an intention to stay and to create new lives for themselves and their families in the new world. Hence, they brought their wives and children along. Typical colonial settlement was a small family farm, especially in the Northern parts of the US. Contrary to this, the Spanish and the Portuguese had a "bounty" mentality. They wanted to get rich and go back home as quickly as possible. Their families were waiting behind in the Iberian Peninsula. It was almost an all male excursion of soldiers, priests and bureaucrats in Southern America. As a result, they were more reckless with the land and the people in the colonies. Also, the land tenure system of the Spanish Empire was very different than that of the British. The Conquistadores were granted huge plots of land (encomienda) in exchange for their service to the Crown. This practice created vast income inequalities that continued to plague Latin America to this day.

\section{American Exceptionalism and the Imperial Mentality}

Any country whose people conduct themselves well can count upon our hearty friendship... Chronic wrongdoing, however, ... ultimately require intervention by some civilized nation, and in the Western Hemisphere the adherence of the United States to the Monroe Doctrine may force the United States ... to the exercise of an international police power.

Theodore Roosevelt (1904)

Unfortunately, the advantages of late colonization, being a product of the Enlightenment generation and the establishment of an open society -thanks to the influence of British political and economic liberalism-, eventually paved the way to the American Exceptionalism phenomenon. Gradually, the US acquired a feeling of "city upon the hill", shinny and brilliant, leading the way to happiness and prosperity for the other less fortunate nations. The signs of this superiority complex were first observed in the Latin American context. The US felt obliged to "teach the Latin Americans how to elect good leaders". 
As the new nation in Northern America acquired more and more power, thanks to the vast resources provided by a vast continent, it began seeking opportunities for territorial expansion towards the south. During the early $19^{\text {th }}$ Century, the Spanish Empire was having military troubles in Europe. Because of this, they were unable to exert full authority in the colonies. In fact, they even put Florida up for sale, in order to finance their military expenses in Continental Europe. The US did not miss this opportunity, and Florida came peacefully under the US rule.

In the first quarter of the $19^{\text {th }}$ Century, Spanish colonies began to declare their independence one after another. Between 1811 and 1825, many new republics emerged, such as Mexico, Colombia and Chile. The US made a rather strategic move by quickly recognizing the independence of these new states. President James Monroe and his Secretary of State John Quincy Adams were trying to weaken the hold of what they called "Old Europe" across the Americas. Below excerpt summarizes the gist of what came to be known as the Monroe Doctrine: that the western hemisphere was closed to European colonization, and any European interference in this hemisphere will be confronting the US power:

The American continents, by the free and independent condition which they have assumed and maintain, are henceforth not to be considered as subjects for future colonization by any European powers. . . we should consider any attempt on their part to extend their system to any portion of this hemisphere as dangerous to our peace and safety. ${ }^{2}$

In light of the Monroe Doctrine, the US constructed its almost two century long hegemony over Latin America. The Roosevelt Corollary that came in 1904 made it clear in no subtle words that the US had acquired the "policeman" status in the region. Between 1898 and 1930, there were 32 US military interventions in Latin America. These interventions continued until the 1990s. In most cases the US intervened in order to bring down left-leaning Latin American governments. Among them, the most infamous was probably the 1973

2"President James Monroe's $7^{\text {th }}$ Annual Address to Congress", 12 December 1823, <www.ourdocuments.gov>, 14 February 2009. 
coup in Chile, which ended the rule of democratically elected socialist President, Salvador Allende.

At the peak of the Cold War, the US was rather intolerant towards the flourishing of leftist political movements "in its own backyard". Thus, the electoral success of the socialists under Allende in Chile raised many eye brows in Washington DC. Initially, the US tried to "make the Chilean economy scream", as Henry Kissinger phrased it, by deploying severe economic sanctions. The funds to Chile that were secured and approved from the World Bank were cancelled in the last minute due to a US government veto. The economic situation was deteriorating in Chile, but not fast enough to provoke a popular overthrow of the socialist government. Under these circumstances, the US resorted to Plan B: instigating a military coup to overthrow the Allende regime. Thus, covert operations by CIA started and finally in September 11, 1973, the military bombed the Presidential Palace and took over the control of the country. From then on, the seventeen-year-long dictatorship of General Pinochet started in Chile. This era was marked in Chilean history with torture, kidnappings, summary executions, and disappearances of political dissidents. Despite its political authoritarianism, Pinochet era was rather liberal in the economic realm. During this period, Chilean economy transformed into a neo-liberal market system. This major overhaul was conducted by a group of technocrats who came to be known as Chicago Boys. They had received their $\mathrm{PhD}$ degrees from the University of Chicago, an institution regarded as the epicenter of supply side economics.

Recent analyses on Cold War era US-Latin American relations highlight one important point: that the US foreign policy during this period was determined largely by an ideological point of view, rather than a dispassionate adherence to US national interests. ${ }^{3}$ Due to its tense competition with the Soviet Union, the US perceived any and all movements that deviated slightly from capitalism as existential threats to its regime and tried to crush them at all expense. This extreme reaction lead to rather unproductive, hypocritical and

\footnotetext{
${ }^{3}$ Jorge Dominguez, "US-Latin American Relations During the Cold War and Its Aftermath", in Victor-Bulmer Thomas and James Dunkerley (eds.), The United States and Latin America: The New Agenda, Cambridge/MA, Harvard University Press, 1999, pp. 33-55.
} 
politically and economically costly US foreign policy decisions. In fact, prominent Realist scholar Hans Morgenthau did not hesitate to call the US "Repression's Friend", because of this unfettered support for military and civilian authoritarian regimes in the 1960s and 1970s. Morgenthau stated that after the World War II, the US was single handedly the most counter-revolutionary force in the world, since it supported the conservative, oppressive and even fascist regimes with such consistency. He also warned against the potential moral and political disasters that might follow such a strategy. ${ }^{4}$

Some of these shady US involvements in Latin America and elsewhere are recently being unveiled, as the time limits on classified documents expire or when more conscientious Presidents come to power. One such case was the declassification of certain national security documents by President Clinton, which came after the wide public opinion pressure that surrounded General Pinochet's arrest in London. According to these declassified documents, President Nixon and his National Security Advisor Henry Kissinger considered the Allende regime in Chile as "unacceptable". The President authorized some form of an intervention and within 48 hours of this speech, CIA had made the coup plans and submitted them to Henry Kissinger. In his own memoirs, Kissinger claims that these coup plans were later tossed away. However, the official CIA documents declassified by the Clinton administration contradict his claims. ${ }^{5}$

All of these documents reveal that the US government utilized all of the financial means at its discretion in order to bring down the Allende government. Later, the US government also supported and funded the Pinochet dictatorship. According to the documents, the US blocked in the last minute a World Bank loan of 21 million dollars to Chile, which would have meant so much for the distressed Chilean economy. Three weeks after the military coup, the US authorized a 24 million dollar loan to Chile, and a subsequent loan of the same amount followed it shortly. The US also gave two destroyers to the Chilean navy. ${ }^{6}$ In fact, US aid for the military juntas in the region was

\footnotetext{
4Hans Morgenthau, "Repression's Friend", The New York Times, 10 October 1974.

5P. Kornbluh, "Declassifying US Intervention in Chile", NACLA Report on the Americas, Vol. 32 (6), May-June 1999, pp. 36-45.

6Ibid., p. 40.
} 
not confined to the Chilean case. In 1964, subsequent to the military coup in Brazil, the US provided a 1,5 million dollar loan to the military regime. ${ }^{7}$

Despite various forms of US interventions in the region, it would be incorrect to conceive US-Latin American relations as monolithic. Regional dynamics are significantly affected by the international context as well as by the domestic politics in each country. For instance while the military coups in Latin America were deliberately supported by Washington during the Cold War, they were severely criticized by many American politicians, activists, academics and political pundits after the 1990s. During the Clinton Presidency, Secretary of State Madeline Albright initiated the process of declassification of CIA archives in order to illuminate the past US role in Chilean coup. These documents left no doubt about the extensive US involvement in General Pinochet's successful coup attempt. Subsequently, the Clinton administration issued an official apology to Chile for the US involvement in the 1973 military coup. This rapprochement, however, was reversed during the Presidency of George W. Bush.

US-Latin American relations experienced a rather bumpy ride during the 1980s and 1990s. The state-centric economic development model of Import-Substitution-Industrialization (ISI), which was strongly advocated by the UN's Economic Commission on Latin American (ECLAC), generated significant bottlenecks. These economic problems brought many countries in the region on the brink of bankruptcy. With failed economic models and broad financial disarray, they became vulnerable to the economic re-structuring models of their capitalist northern neighbor. Hence, the neoliberal era of Latin America started under the auspices of the US and global financial powerhouses in Washington DC (IMF and the World Bank).

Latin America was deeply affected from what came to be known as the "Washington Consensus." Most countries in the region took the "bitter pill" and endured the "shock therapy", which included the following: Privatization of the state-owned industries, reduction of state expenditures, elimination of subsidies,

${ }^{7}$ D. Slater, "Imperial Geopolitics and the Promise of Democracy", Development and Change, Vol. 38 (6), 2007, pp. 1041-1054. 
liberalization of capital and financial markets, floating exchange rates, export-orientation, abolition of tariffs and quotas. ${ }^{8}$ Both larger and smaller economies in the region undertook significant structural adjustment measures with the hope that this new economic model would uplift all boats.

Unfortunately the 1980s -when structural adjustment and orthodox neoliberal reforms were at full swing- turned out to be a lost decade for Latin America. By the 1990s, the top two institutions that advocated this model had switched to a different jargon. Those who had argued that markets would cure all ills that state-driven economies had generated, were now emphasizing the role of state and "good governance." 9 By the new millennium, collateral damage in Latin America in the form of stagnant growth, worsening income inequality, growing marginalization and social unrest was obvious. Prominent economists began voicing what has long become a grave political reality. It was absolutely necessary to address the plight of the poor and formulate socially, politically and environmentally sustainable development models. ${ }^{10}$

\section{1 ${ }^{\text {st }}$ Century: Economic Growth and Democratic Deepening in Latin America}

With the start of a new century, a different political wind was making its way across Latin America. Two decades long neoliberal reform had created sizeable chunks of opposition in many countries. In Brazil, Argentina, Chile, Venezuela and even in Mexico, left was becoming a formidable electoral force. End of the Cold War and subsequent relaxation in the US attitude towards leftist social movements in the region also created a favorable atmosphere for this left-turn in Latin America. Below is a list of some of the elected Heads of State in the region with leftist credentials.

\footnotetext{
${ }^{8}$ John Williamson, "What Washington Means by Policy Reform", in John Williamson (ed.), Latin American Readjustment: How Much has Happened, Washington, Institute for International Economics, 1989.

${ }^{9}$ Beyond the Washington Consensus: Institutions Matter, Washington DC, World Bank Publications, 1998.

${ }^{10}$ Dani Rodrik, One Economics, Many Recipes: Globalization, Institutions, and Economic Growth, Princeton, Princeton University Press, 2007.
} 
- Brazil 2002 and 2006: Luiz Inacio Lula da Silva, socialist (Worker's Party), worker and union organizer, emphasizes social policies that target redistribution and income equality

- Argentina 2003: Nestor Kirchner, center-left, Peronist, emphasizes economic growth based on production, not financial speculation, transparency and accountability (Followed by his wife Cristina Fernandez de Kirchner in 2007 elections)

- Uruguay 2005: Tabare Vasquez, center-left (Frente Amplio), food aid, health care and other social policies dominated his agenda, brought the 1970s coup leaders in front of justice, political crimes uncovered

- Bolivia 2005: Evo Morales, socialist, coca farmer, leader of cocalero movement, first President of indigenous (Aymara) origin.

- Chile 2006: Michelle Bachelet, socialist, atheist, pediatrician, her father was killed under torture during Pinochet years, her policies endorsed economic growth and equitable redistribution.

- Nicaragua 2006: Daniel Ortega, leader of the Sandinista movement that fought against the US-financed contra-guerillas in the 1980s, supports land reform

- Ecuador 2007: Rafael Correa, humanist, Christian-left, confronted the international energy and finance giants for better terms in their relations with Ecuador, emphasizes social policies

- Venezuela 1999-2006: Hugo Chavez, military officer, advocates socialism of $21^{\text {st }}$ century, social policies, equitable redistribution, production based on collective ownership, local/grassroots organization, direct democracy

- Paraguay 2008: Fernando Lugo, Catholic bishop, also known as the "Bishop of the poor".

This leftist turn in Latin America had significant returns for Latin America. From a political perspective, it opened up a huge wave of collective activism and citizen participation at the grassroots level. In almost every conceivable issue, from neighborhood beautification projects to access to potable water, from union rights to human rights, grassroots communities gained significant voice. In Argentina and Chile, human rights groups pushed for uncovering the atrocities committed by military juntas and brought the perpetrators in front of justice. Truth and reconciliation commissions were established in many countries largely due to the consistent pressures of organized civilian initiatives. In Brazil, citizens organized to have 
more direct voice in local government and established the practice of participatory budgeting. The residents of Mexico City were fed up with the disorganized state services after the tragic earthquake; hence they themselves took charge of the relief effort. All in all, these social movements established a vibrant public forum as well as a robust civil society across Latin America. ${ }^{11}$ They pushed for more transparency, accountability and more direct participation in the political decision making, which eventually deepened and improved the quality of democracy in Latin America.

The leftist-turn in Latin America had substantial economic gains as well. At the domestic level, nations with some of the least equitable income distribution, such as Brazil or Venezuela, managed to improve the lot of the poor, thanks to the programs initiated by Presidents Hugo Chavez and Lula da Silva. Today, over half of the Brazilian population $(52 \%)$ constitutes the middle classes. ${ }^{12}$ At the regional level, Latin American countries accomplished an impressive economic performance as well. Chart 1 and Table 1 below illustrate the overall size of Latin American and Middle Eastern countries. As both clearly indicate, Latin American economies display an impressive performance. If we add up just the economies of Brazil and Mexico together, the largest 10 economies in the Middle East (Turkey, Iran, Saudi Arabia, Egypt, Israel, UAE, Kuwait, Syria, Lebanon, Qatar) can barely match their size. And it is not just a matter of size, but also content of the economic output as well. Latin America as a region is a lot more diversified, and a lot less dependent on raw material exports than the Middle East. Many countries in the region are becoming exporters of more technologically advanced and higher value-added products. Both Brazil and Mexico are significant players in automotive industry. Brazil now competes with the global giants of the airline industry. Brazilian airline company EMBRAER is the $3^{\text {rd }}$ largest airplane manufacturer in the world today, following Airbus (EU) and Boeing (US).

${ }^{11}$ Arthur Domike (ed.), Civil Society and Social Movements, Inter-American Development Bank, 2008.

${ }^{12}$ Luiz Inacio Lula da Silva, "Building on the B in BRIC", Economist - The World in 2009, 19 November 2008. 
2008] DECLINING US INFLUENCE AND RISE OF LATIN AMERICA’S 111 REGIONAL POWER

CHART 1: Sizes of Selected Latin American, Middle Eastern and Turkish Economies in Comparative Perspective

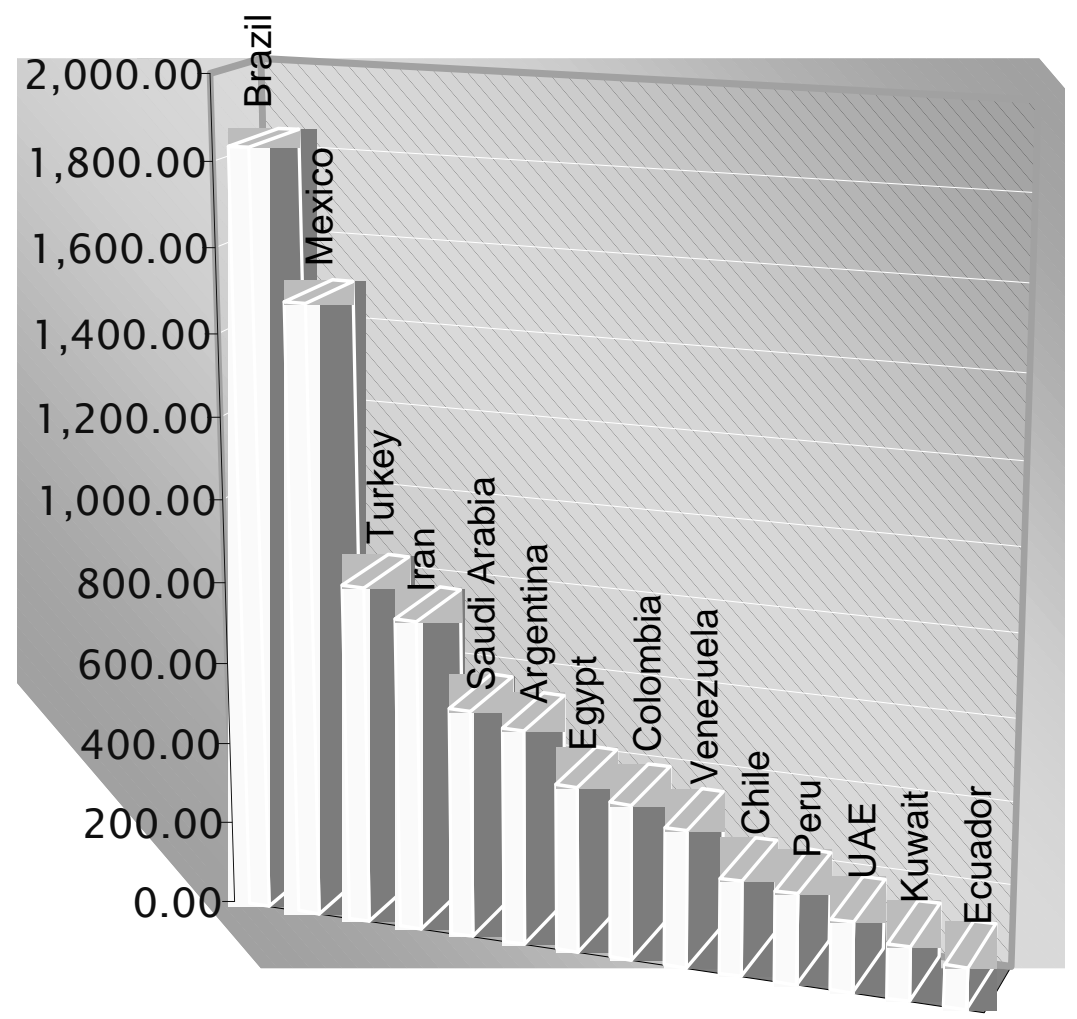


TABLE 1: Size of Economy, Population, and Military Expenditures of Latin American and Middle Eastern Countries

\begin{tabular}{|c|c|c|c|c|c|}
\hline & COUNTRY & $\begin{array}{c}\text { GDP, 2007, } \\
\text { ppp adjusted, } \\
\text { in billion US } \\
\text { dollars }\end{array}$ & $\begin{array}{l}\text { Population } \\
\text { (2007) } \\
\text { in millions }\end{array}$ & $\begin{array}{c}\text { Military } \\
\text { Expenditure } \\
(2007) \\
\text { in constant } \\
\text { million US } \\
\text { dollars } \\
\end{array}$ & $\begin{array}{c}\text { Military } \\
\text { Expenditure } \\
\text { as \% of GDP } \\
(2006)\end{array}$ \\
\hline 1 & Brazil & $1,837.15$ & 189.3 & 15,334 & 3.6 \\
\hline 2 & Mexico & $1,486.30$ & 105.2 & 3,691 & 0.4 \\
\hline 3 & Turkey & 824.578 & 68.8 & 11,066 & 2.9 \\
\hline 4 & Iran & 757.488 & 71.6 & 6,592 & 4.6 \\
\hline 5 & Saudi Arabia & 555.055 & 24.2 & 33,793 & 8.5 \\
\hline 6 & Argentina & 524.14 & 39.3 & 1,752 & 0.9 \\
\hline 7 & Egypt & 404.293 & 73.5 & 2,706 & 2.7 \\
\hline 8 & Colombia & 378.624 & 47.5 & 5,329 & 4 \\
\hline 9 & Venezuela & 334.85 & 27.5 & 2,004 & 1.2 \\
\hline 10 & Chile & 230.863 & 16.5 & 4,821 & 3.6 \\
\hline 11 & Peru & 219.196 & 28 & 1,133 & 1.3 \\
\hline 12 & Israel & 188.93 & 6.9 & 12,233 & $8^{*}$ \\
\hline 13 & UAE & 170.28 & 4.4 & .. & .. \\
\hline 14 & Kuwait & 130.239 & 3.3 & 4,400 & 4 \\
\hline 15 & Ecuador & 99.43 & 13.7 & 1,196 & 2.3 \\
\hline 16 & Syria & 87.163 & 19.4 & 5,703 & 5.1 \\
\hline 17 & Libya & 82.769 & 6 & 513 & 1.1 \\
\hline 18 & Qatar & 79.659 & 0.9 & .. & .. \\
\hline 19 & Azerbaijan & 65.523 & 8.6 & 667 & 3.6 \\
\hline 20 & Guatemala & 62.58 & 13.3 & 149 & 0.4 \\
\hline 21 & Oman & 61.658 & 2.5 & 3,813 & 11.2 \\
\hline 22 & Yemen & 52.216 & 22.2 & 820 & 4.3 \\
\hline 23 & Costa Rica & 46.021 & 4.4 & 0 & $0 * *$ \\
\hline 24 & Lebanon & 42.306 & 3.7 & 1,284 & 4.6 \\
\hline 25 & Bolivia & 40.14 & 9.8 & 141 & 1.4 \\
\hline
\end{tabular}



REGIONAL POWER

\begin{tabular}{|l|l|r|r|r|c|}
\hline COUNTRY & $\begin{array}{c}\text { GDP, 2007, } \\
\text { ppp adjusted, } \\
\text { in billion US } \\
\text { dollars }\end{array}$ & $\begin{array}{c}\text { Population } \\
\mathbf{( 2 0 0 7 )} \\
\text { in millions }\end{array}$ & $\begin{array}{c}\text { Military } \\
\text { Expenditure } \\
\text { (2007) } \\
\text { in constant } \\
\text { million US } \\
\text { dollars }\end{array}$ & $\begin{array}{c}\text { Military } \\
\text { Expenditure } \\
\text { as \% of GDP } \\
\text { (2006) }\end{array}$ \\
\hline 26 & Uruguay & 37.357 & 3.2 & 249 & 1.3 \\
\hline 27 & Panama & 34.605 & 3.3 &.. &.$* * *$ \\
\hline 28 & Jordan & 28.079 & 5.7 & 988 & 5 \\
\hline 29 & Paraguay & 27.207 & 6 & 65 & 0.8 \\
\hline 30 & Bahrain & 24.373 & 0.7 & 543 & 3.5 \\
\hline
\end{tabular}

Average military expenditure as \% of GDP in Latin America: 1.5\%

Average military expenditure as \% of GDP in Middle East \& North Africa: 4.9\%

(Author's calculations, based on above data)

.. data not available

*Includes US military aid to Israel, \$2,34 billion in 2007.

** Costa Rica does not have any armed forces.

***Panama military force was abolished in 1990 , and replaced by national police, air and maritime services.

Only the larger countries (by economic size and population) are included in the list above.

Data Sources:

First two columns (GDP and Population) are gathered from the World Economic Outlook Database 2008, International Monetary Fund (IMF), 〈www.imf.org〉, 14 February, 2009.

Data on military expenditures and its percentage in GDP are gathered from the Military Expenditure Database, Stockholm International Peace Institute (SIPRI), $<w w w . s i p r i . o r g\rangle$.

While most of the developing world rendered a passive role vis-à-vis the untamed capitalist system, Latin American countries are displaying an impressive performance in the last decades. They were able to create viable regional cooperation mechanisms. The Common Market of the South (MERCOSUR) is already an up and coming institution, covering an area four times the European Union and encompassing 250 million people. It was formed by Brazil, Argentina, Paraguay and Uruguay and currently has Bolivia, Chile, Colombia, Ecuador and Peru as associate members. Aside from MERCOSUR, there is another initiative in the region which aims to extend beyond commercial relations. In President Lula da Silva's own words: "The Union of South American Nations (UNASUL), which 
aims to enhance regional integration and to ensure a stronger international presence for our block. UNASUL is setting up an energy plan, a defense council and a development bank."13

Even the distressed economies in Latin America region can find assistance outside the IMF-World Bank financial monopoly. When Argentina was in a dire situation, Venezuela came to its help by providing oil in exchange for cattle and beef. Likewise, the economic hardships in Cuba were largely mitigated by employing thousands of Cuban doctors across Latin America (particularly in Venezuela) and trading the essential consumption items in exchange for this highly qualified workforce. ${ }^{14}$ In short, Latin American countries are showing greater solidarity as a region. Instead of fighting solitary battles, they are pooling their energies and are collectively trying to address the most difficult economic problems of the $21^{\text {st }}$ Century.

Historically, Latin America seems to have suffered a lot from the US hegemony and there is certainly a palpable discontent in the region against the "unipolar world" that emerged since the collapse of the Soviet bloc. Many countries in Latin America are uncomfortable with the current unipolar system. In fact, even the most pro-US countries in the region, such as Mexico, do not shy away from taking positions against the superpower's wishes. A prominent example of this was displayed when the US tried to bully a resolution out of the Security Council before the Iraq war in 2002. The two rotating members of the Security Council, Mexico and Chile, had significant commercial ties with the US. Yet, neither of them supported the US position at the UN. In the case of Cuba, where the US continues its half a century long blockade, nearly all Latin American countries defy the US embargo and continue to have close ties with the island. Despite the long history of hegemonic domination, there seems to be growing defiance in Latin America today (spearheaded by outspoken leaders like Chavez and Morales). Even more moderate leaders are expressing discontent with the US. In an interview in the Time Magazine, President Cristina Fernandez de Kirchner (of Argentina)

\footnotetext{
13 Ibid.

${ }^{14}$ Evren Çelik Wiltse, "Hugo Chavez ve Venezuela'da Gelişen 21. Yüzy1l Sosyalizmi”, Birikim, Vol. 203, March 2006, pp. 37-44.
} 
stated the following regarding the US-Latin American relations:

Chavez's threat to the U.S. is more verbal than actual. But more urgent here is the question of multilateralism. The fall of the Berlin Wall made the U.S. a superpower with a unilateral character; and the unilateral decisions it has made in recent years, like the invasion of Iraq, outside the United Nations and international law, have caused the world a lot of problems. ${ }^{15}$

The US "war on terror" and its intense engagement in the Middle East seem to have been a great blessing for Latin America. Without the overbearing presence of a superpower in the region, Latin American countries were able to operate in a relatively less constrained manner. They have successful utilized this 'superpower vacuum' to facilitate regional cooperation, and establish stronger economic ties based on their mutual strengths. Politically, the region also began to acquire a distinct international recognition. Nearly all countries in the region are democracies. Without the meddling of the US, many countries have established popular regimes that address the problems of long time marginalized sectors of the society. In some cases, Presidents of indigenous origin were able to come to power for the first time in their modern history. It is no coincidence that after the relative decline of the US power in Latin America, left-leaning regimes in the region strengthened in almost every country.

As a region, Latin America seems to be putting its house in order both economically and politically. Arguably, the only area where no significant progress have taken place is Colombia, -a country with significant US military involvement. The US fight against narco-trafficking in this country seems to have perpetuated the instability and civil war. In the rest of the continent, as well as in the Caribbean, there is steady progress towards greater political freedom and economic prosperity. Table 1 above is a clear indicator of the growing economic strength and declining military/security threats in the region. As seen in their comparatively small military expenditures, regional security is no longer a high priority for the Latin American countries. This enables them to re-allocate valuable funds in more productive and socially responsive ways, instead of

15"Interview: Cristina Fernandez de Kirchner of Argentina", Time, 29 September 2007. 
buying expensive weapons technologies. In fact, two countries in the region (Costa Rica and Panama) have altogether abolished their militaries. On average, Latin American countries spend only $1.5 \%$ of their GDP's on military, whereas in the Middle East nearly 5\% of the GDP $(4.9 \%)$ is allocated to military and defense related spending. Thus, the relatively high price Middle Eastern countries pay for their security becomes even more striking when compared with Latin America.

\section{Some Comparative Lessons for Turkey and the Middle East}

Despite the unique circumstances of each nation, they all are influenced by the regional and global (systemic) dynamics to some degree. The security and prosperity prospects of a nation are intimately tied to both domestic and regional/international variables. Living in a prosperous region with friendly and stable neighbors would certainly provide a positive impetus. Yet, in regions with high security threats and endemic conflict, security and defense concerns will take priority over everything else, including development, economic prosperity, income distribution, democratic participation, etc. In short, regions can be both the problem and the solution. Development regionalism may contribute to the economic prosperity of member states. Security regionalism may diminish the perception of threat and contribute to mutual trust and stability among members. ${ }^{16}$ On the other hand, high-threat, high-conflict regions are less conducive to replicate the development and democratization model as discussed above in the Latin American case.

In the case of Turkey, the number of regional influences multiplies, since Turkey is a country that enjoys a "bundle of linkages". With one foot at the door of the European Union and another in the Middle East, Turkey is exposed to more than one regional influence. The country is simultaneously praised and lamented as a "bridge" across many regions. This fact creates difficult variables for the country to juggle. Below, Philip Robins

16Björn Hettne, “Teori ve Pratikte Güvenliğin Bölgeselleşmesi”, Uluslararası İlişkiler, Vol. 5 (18), Summer 2008, pp. 87-106. 

REGIONAL POWER

lucidly summarizes the difficulties of this particular geographic location:

Turkey "...sought to enter a variety of clubs of states both west and east. Thus it is a member of Council of Europe and NATO on the one hand, and the Islamic Conference organization (ICO) on the other. In this way, and in claiming to be part of both the secular and the Islamic worlds, Turkey has sought to make the best of its foothold in two continents. ... But politically and philosophically, the claim collapses. The truth is that, rather than understanding both continents and both cultures, and hence having a unique role as interpreter to both, Turkey comprehends neither adequately to fulfill this role. Its relationship with the Arabs, the Persians and the majority of the Islamic states is confused and tentative. Its relationship with the West is increasingly marked by suspicion and resentment. ${ }^{17}$

Although Philip Robins displays the regional connections of Turkey in a grim tone, his observations are accurate about the limbo position that the country is suffering from. On the one hand, there is the so-called European anchor that is never really strong enough to transform Turkey into a fully developed and democratized society. On the other hand, there are the Middle Eastern neighbors that seem to be only liability for Turkey, rather than asset. The forty-year-old gridlock on the Israel-Palestine issue, lack of democratic governance among Arab states, sectarian battles, constant tension between Sunni Arabs and Shia Persians, easy access to natural resources and distorted state structures as a result of this (i.e. rentier states), and superpower meddling to control the natural resources all contribute to a toxic mix of regional instability in the Middle East. Sectarianism and mutual distrust hampers the possibilities of regional cooperation and collective action.

As the largest economy in the Middle East, Turkey is deeply affected from the toxic environment in the region. For the longest time, Turkey chose to be a status quo power, avoiding any proactive role in the region. Starting from the 1990s, there were spurs of activism, largely due to the characters of new political leaders in Turkey. The first of these figures was Prime Minister Turgut Özal.

${ }^{17}$ Philip Robins, Turkey and the Middle East, London, Chatham House, 1991, pp. 14-15 
Özal's can-do type personality was key to his efforts to mobilize economic ties between the Turkish businesses and the Middle Eastern and Gulf economies. However, "his bold approach would not bear fruit." Özal's plans to establish a peace pipeline did not materialize due to "regional mistrust and Arab fear of becoming dependent on Turkish water." In fact, all this activism did was to increase the concerns and suspicions among Arab countries on Turkey's intentions to dominate the region. ${ }^{18}$

Other times, Turkey's efforts to become more actively engaged in the Middle East yielded humiliating results. During the brief Prime Ministry of Necmettin Erbakan, Turkey changed its orientation towards the Middle East and the Muslim world once again. Erbakan made his first official visits to countries like Iran, Libya and Egypt, clearly seeking a welcoming hand in the region. Yet, each of these visits were marked with diplomatic scandals and turned out to be a disappointment for the Erbakan government. ${ }^{19}$

Lenore Martin calls the Middle East and "innately unstable region". The perennial problem between Israel and Palestine is about to celebrate its golden anniversary, thanks to the lack of regional will and solidarity to resolve it in a just and conclusive manner. On the one hand, Egypt strikes "separate peace" deals with Israel, while on the other, most Arab nations are suspicious of Iran trying to spread the Islamic revolution. ${ }^{20}$ Meanwhile, some countries in the region are notorious for hosting terrorist groups and even supporting them in order to blackmail their neighbors. When security is tentative and mutual distrust runs so high in the region, Turkey's national interests are immediately geared towards national security.

Middle East seems to be far from replicating the security and developmental regionalism models that are displayed in the Latin

\footnotetext{
${ }^{18}$ Kemal Kirişçi, "Turkey and the Muslim Middle East", in Turkey's New World, Alan Makovsky and Sabri Sayarı (eds.), Washington DC, Washington Institute for Near East Policy, 2000, pp. 40-41.

${ }^{19}$ Gencer Özcan, "Yalan Dünyaya Sanal Politikalar", in Onbir Aylık Saltanat, Gencer Özcan (ed.), İstanbul, Boyut, 1998, pp. 183-84.

${ }^{20}$ Lenore Martin, “Turkey's Middle East Foreign Policy", in The Future of Turkish Foreign Policy, Lenore Martin and Dimitris Keridis (eds.), London\&Cambridge, The MIT Press, 2004, pp. 157-190.
} 
2008] DECLINING US INFLUENCE AND RISE OF LATIN AMERICA'S 119 REGIONAL POWER

American context. This fact necessarily affects the foreign policy prospects of Turkey. While Turkey is the only country that carries warm relations with Israel, Syria, Iran, Egypt and most other countries in the region, these relations are mostly bilateral. It is very difficult for the countries in the Middle East, and as well as for Turkey, to fully realize their potentials and establish prosperous and democratic regimes, without collectively transforming the region into a dense network of mutual trust and cooperation. 